DOI: https://doi.org/10.34069/AI/2021.48.12.3

How to Cite:

Opanasiuk, O., Shyp, S., \& Oleksiuk, O. (2021). Impressionism in the context of procedural nature of existence of European culture. Amazonia Investiga, 10(48), 26-33. https://doi.org/10.34069/AI/2021.48.12.3

\title{
Impressionism in the context of procedural nature of existence of European culture
}

\section{Імпресіонізм у контексті процесуального буття Свропейської культури}

Received: November 1, 2021

\begin{abstract}
Impressionism has been studied in the context of the procedural nature of European culture and the peculiarities of its development in the final intentional formation period. Cultural, comparative and analytical methods of analysis are used. The article emphasizes: since the beginning of European culture, its artistic development has determined the desire to express images of the world in their real and objective perspective. It achieves this in the 19th century. The analysis gives grounds for the following conclusion. At the turn of the 19th -20 th centuries the vector of observation of images of the world changes. Culture forms an intentional reflection, which determines its cultural and artistic development. The object perspective loses its relevance, but the movement from the (specific) object towards the periphery and the deep dimension of phenomena becomes decisive for art. Impressionism expresses only one aspect of such movement and it is directed towards the deep sphere of the object. Impressionism is characterized by the phenomenological principle of artistic representation.
\end{abstract}

Keywords: Impressionism, culture, object perspective, intentional reflection of culture, intentional-phenomenological concentration.
Accepted: December 15, 2021

\author{
Written by: \\ Oleksandr Opanasiuk \\ https://orcid.org/0000-0002-2685-9468 \\ Sergey Shyp ${ }^{6}$ \\ https://orcid.org/0000-0003-2569-4240 \\ Olha Oleksiuk \\ https://orcid.org/0000-0002-7785-1239
}

\begin{abstract}
Анотація
Імпресіонізм досліджується в контексті процесуальності Європейської культури та особливостей iї розвитку в заключний інтенціональний - період становлення. Використовуються культурологічний, порівняльний і аналітичний методи аналізу. У статті наголошується: від початку становлення Європейської культури їі художній розвиток визначає прагнення виразити образи світу в їхній реальній та об'єктній перспективі. Цього вона досягає в XIX ст. Проведений аналіз дає підставу для такого висновку. На рубежі XIX-XX ст. змінюється вектор спостереження образів світу. Культура формує інтенціональну рефлексію, яка детермінуе іiі культурнохудожній розвиток. Об'єктна перспектива втрачає актуальність, натомість рух від (конкретного) об'єкта в бік периферії та глибинного виміру явищ стає визначальним для мистецтва. Імпресіонізм виражає лише один аспект такого руху і спрямований до глибинної сфери об'єкта. Для імпресіонізму характерний феноменологічний принцип художнього відображення.
\end{abstract}

Ключові слова: імпресіонізм, культура, об'єктна перспектива, інтенціональна рефлексія культури, інтенціональнофеноменологічне зосередження.

\footnotetext{
${ }^{5}$ Doctor of Art Criticism, Professor of the Borys Hrinchenko Kyiv University, Ukraine.

${ }^{6}$ Doctor of Art Criticism, Professor of the Department of Music and Choreography at the Ushinsky South Ukrainian National pedagogic university, Ukraine.

${ }^{7}$ Doctor of Pedagogical Sciences, Professor, Head of the Chair of Musicology and Music Education, Borys Hrinchenko Kyiv University, Ukraine.
} 


\section{Introduction}

Impressionism emerged in European culture in the last third of the $19^{\text {th }}$ century. Although the first impressionist trends were manifested in the visual arts in the 1860s (Edgar Degas, Edouard Manet, Pierre Auguste Renoir), the beginning of the Impressionism development as a stylistic phenomenon should be considered 1874, after the exhibition of "independent" artists, which displayed a painting by Claude Monet "Impression. Sunrise" ("Impression. Soleil levan”, 1872). By analogy with Louis Leroy's article "Exhibition of the Impressionists", ("L'exposition des impressionnistes", 1874) a new style was called "impressionism”.

The intensive development of Impressionism in painting and literature lasted for more than a decade. In 1886, the last exhibition of Impressionist artists was held, and in the same year, the French symbolist poet Jean Moréas published "The manifesto of symbolism" ("Le Symbolisme"). After these events, Impressionism was interpreted as postimpressionism. At the same time, it should be noted that there is no clear distinction between impressionism and post-impressionism. A lot of artists whose works were written after 1886 had common features with impressionism.

A slightly different picture appeared in music, regarding impressionism. At the end of the $19^{\text {th }}$ century, the impressionist style actively showed its signs in the works of Claude Debussy, Maurice Ravel, Ernest Chausson, Paul Dukas and Eric Satie. Its development finished with the outbreak of the First World War, that was, in 1914. As such, post-impressionism does not exist in music. We can only talk about impressionist trends in the works of composers from different countries, as well as the influence of impressionism on European development and world music of the $20^{\text {th }}-21^{\text {st }}$ centuries.

What has been said about Impressionism corresponds to the established point of view regarding its positioning as an artistic style. However, today the ontology of cultural and artistic phenomena in their macro-historical and deep basis is becoming relevant. These trends can be explained by the circumstances when European culture is in the period of old age (late $19^{\text {th }}-20^{\text {th }}$ centuries; Spengler, 1993), or in the final intentional period (late $19^{\text {th }}-21$ th centuries; Opanasiuk, 2020) directs attention to the analysis and the result of its formation.
Therefore, Impressionism can be considered as the first (but not the only one) reflection of this kind and reflection on the completed cultural and artistic development. The analysis of Impressionism in the macro historical cultural perspective lays the foundations for the deep ontology of this style and the artistic and stylistic development of European culture in the final intentional period of its formation.

\section{Methodology}

Analysis of Impressionism uses culturological, comparative and analytical research methods. The culturological method is aimed at determining the style of Impressionism in the context of the procedural existence of European culture. The comparative method is aimed at comparing the development of the style of Impressionism in the fine and musical arts. The analytical method is aimed at analyzing various semantic aspects of Impressionism. The use of these methods makes it possible to show in which historical period of formation of culture impressionism arises and to objectify its content.

\section{Analysis of bibliography and range of problems of the article's topic}

Impressionism as an artistic phenomenon is described in numerous scientific monographs, encyclopedias, and articles. It is necessary to keep in mind countless publications aimed at defining its stylistic expressive features, features of Impressionism as a cultural and artistic phenomenon, etc. (e.g.: Venturi, 2007; Rewald, 1973; Bomford, 1991; World Art, 2008; Eisenman, 2011).

Musical impressionism in the scientific literature is also comprehensively covered; the work of composers from different countries whose musical works are based on impressionistic aesthetics is also analyzed (e.g.: Palmer, 1973; Kennedy, 2006; Kushniruk, 2008).

At the same time, it should be noted that in such cases the historical epoch, stylistic changes in musical culture, peculiarities of revealing stylistic features of impressionism in artistic phenomena, musical works, difference of musical impressionism from music of romanticism are mostly analyzed.

An example is any publication that analyses the works of musical impressionist classics Claude Debussy (Vuillermoz, 1957; Trezise, 2003), 
Maurice Ravel (Mawer, 2000; Nichols, 2011), as well as works by many twentieth-century composers with a pronounced impressionistic aesthetic.

Of course, such analytics make it possible to identify the characteristic features of the Impressionist style and the principles of its implementation in musical culture. However, as it noted in the introduction to the article, the ontology of artistic phenomena in their macrohistorical perspective and deep basis suggests a different angle of research. In this case, the culture existence becomes important. To this must be added the following.

Any artistic and stylistic phenomena belong to a certain era in which they develop. At the same time, each epoch belongs to the space of a certain culture, the content of the formation of which it accordingly determines. All this indicates that culture is a living social organism with its inherent procedural and structural existence. Therefore, it is evident that cultural and artistic phenomena are determined by the procedural and structural nature of the formation of culture. Moreover, outside of these aspects, it is difficult to talk about the laws of cultural and artistic development, as well as about the very content of cultural and artistic phenomena. It is also obvious that outside of these circumstances it is impossible to reach the ontological level of artistic phenomena in their macro-historical perspective and deep basis.

In the science of $20^{\text {th }}$ century, only the theories of Oswald Spengler (1993), Arnold Toynbee (1995), and Lev Gumilev (2005) can be mentioned, which do not leave questions of the procedural and structural nature of cultural existence. To a certain extent, these include the philosophical and cultural theory of Georg Hegel (2007). In the works of Oleksandr Opanasiuk (2014; 2020), the procedural and structural nature of European culture has been determined on the basis of identifying four periods of its development: the symbolic period (Middle Ages, Renaissance, $5^{\text {th }}-16^{\text {th }}$ centuries); classical period (Modern Times, Enlightenment, $17^{\text {th }}-18^{\text {th }}$ centuries); romantic period (19 $9^{\text {th }}$ century); intentional period (late $19^{\text {th }}-21^{\text {st }}$ centuries).

\section{Results and Discussion}

For the ontology of Impressionism, as well as for determining the deep content of any artistic phenomenon, it is necessary to answer the following questions: 1) What does Impressionism imply in terms of expressing images of the world?; 2) How does it seek to do this? 3) What is the reason for the artistic practice of Impressionism and how does it differ from the semantic foundations of previous styles? 4) What cultural foundations determine the emergence of the Impressionist style?

Since outside the existence of culture one should not look for the true reason for the certain artistic phenomena development, it is clear that the answer to the first three questions must take into account the fundamental basis of the fourth position (cultural section) and build on it analytical discourse.

First of all, it should be noted that different sources (encyclopedias, dictionaries, monographs, articles) approximately equally outline the principles of artistic expression characteristic of Impressionism in art. For example:

"Term used in visual art from 1874 to describe the work of Monet, Degas, Whistler, Renoir, etc., whose paintings avoid sharp contours but convey an 'impression' of the scene painted by means of blurred outlines and minute small detail..." (Kennedy, 2006); “...The artistic concept of Impressionism was based on the desire to naturally and easily capture the surrounding world in its variability, transmitting its fleeting impressions..." (World Art, 2008); “...Musical impressionism brings colorfulness, the desire for the embodiment of instant impressions..." (Kushniruk, 2008).

If we take into account the texts of these definitions and the principles characteristic of Impressionists, then we can answer the first question and state: in terms of expressing images of the world, Impressionism involves relying on changing states of mind, changing sensations, changing images, blurring and indistinctness of the outlines of objects in the image.

Increased attention to sound, timbre makes it possible to express the depth of being: "Timbre's paradoxical im/materiality engenders a sublime aesthetic experience that can be described as the aporia of being drawn into a void which appears to be real but which - the closer you get to it flickers in and out of earshot and comprehension" (Elferen, 2017). Claudy Malherbe (2000) notes the same; the title of his article highlights similar points: "Seeing Light as Color; Hear the Sound as a Timbre".

Such a focus on the meanings of the means of expression determines the music of many 


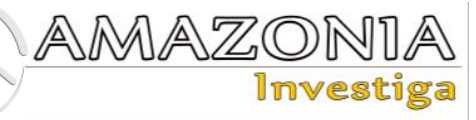

composers of the twentieth century. An example is the Messiaen. He builds his musical poetics on the principle of selecting the musical meanings of various works of past centuries. This principle (in relation to Debussy) is the subject of analysis of Balmer's article "Messiaen the Borrower: Recomposing Debussy through the Deforming Prism" (Balmer et al, 2016).

However, this conclusion does not yet fully clarify the content of the artistic practice of Impressionism. After all, the principles of instant and impermanence of artistic expression largely determined romantic art.

It is possible to understand the deep meaning of the Impressionist style only if the context is updated. Our attention will be directed to the fundamental contextual basis, which is the existence of a particular culture, that is, its intention, procedural nature.

The intention of European culture is significantly different from the intention of previous cultures and those cultures that co-existed with it and coexist in a certain time space. The difference lies in the fact that its artistic development is due to the desire to express real images of the surrounding world in their object perspective (In this case, objectivity is interpreted as the expression of real images of the world in works of art, including with the embodiment of psychological experiences and sensations of a person in them.).

Apparently that this principle is not typical for previous cultures, which mainly focused on the general principle of artistic reflection, that is, on art in which the general content idea and the general content of the image are expressed.

At the beginning of the formation of European culture, the principle of objectivity could not yet be implemented, but this intention constantly directed its development to the possibility of such an image and expression, which became possible for it in the $19^{\text {th }}$ century. This means that the works of art of this century correspond to the real images of the surrounding world, that the artistic image reaches the level of its real, concrete and corresponding to the images of the surrounding world object existence.

At one time in "Aesthetics" Georg Hegel (2007) noted that the formation of an idea involved symbolic, classical, and romantic stages of development. And that only at the third stage can the idea fully implement its attributes, after which it proceeds to deny what has been done (this aspect is discussed below).

In the works of Oleksandr Opanasiuk (2014; 2020), German philosopher's concept is supplemented by the fourth component that is the intentional form. At the same time, the concepts of "symbolic", "classical", "romantic", "intentional" are used to characterize the procedural existence of European culture. It is obvious that these concepts make it possible not only to determine the content of its procedural nature, but also to objectify the content of its artistic development.

If we take into account that the dynamics of European culture are determined by the symbolic $\left(5^{\text {th }}-16^{\text {th }}\right.$ centuries $)$, classical $\left(17^{\text {th }}-18^{\text {th }}\right.$ centuries), romantic $\left(19^{\text {th }}-21^{\text {st }}\right.$ centuries $)$, intentional (late $19^{\text {th }}-21^{\text {st }}$ centuries) periods (Opanasiuk, 2020, 154), It is not difficult to understand what happened in art at the turn of the third and fourth periods of its development.

In particular, in the $19^{\text {th }}$ century, the music development was aimed at strengthening the individualization of musical themes, musical images, expanding the expressive palette of music (alterations, chromaticism, expansion and complication of classical key), and developing formative principles. All this contributed to the fact that in the second half of the $19^{\text {th }}$ century, musical art could already express the most diverse images in content and create works of art at the level of their object existence. In fact, musical works of this period, as well as works of other types of art, are original and individualized cultural and artistic objects that reflect the real content of images of the surrounding world.

To answer the second and third questions defined above (how does Impressionism express images of the world?; what is the reason for its artistic practice and how does it differ from the semantic foundations of previous styles?) it is necessary to update the cultural factor, that is, to find out what cultural foundations determine the emergence of the Impressionist style.

In this case, it is appropriate to turn to the "Aesthetics" of Georg Hegel, where at the end of the second part he explains the possible prospect of developing an idea and artistic culture after they fully realize their attributes. The German philosopher argues that after the implementation of the semantic program of the idea, which occurs at the third stage of its formation, after a comprehensive disclosure of views on the world, art turns against its previous development, resorts 
to irony (about the accomplished and the past); at the same time, art seeks to find the answer to any questions in itself (Hegel, 2007, 611, 613).

If the artistic development of European culture in the context of its characteristic principle of expressing an artistic image at the level of its objectivity is transferred to its procedural existence, then we can state the following.

The movement to the object (specific object) determined the content of the artistic development of European culture during the first two, to a large extent the third periods $\left(5^{\text {th }}-16^{\text {th }}\right.$ centuries; $17^{\text {th }}-18^{\text {th }}$ centuries; $19^{\text {th }}$ centuries), while the movement from the object (from a specific object) acquires significance after reaching the previous one, that is, in the intentional (final) period. It is obvious that movement from a (specific) object is a movement towards the periphery or a movement towards the deep dimension of the phenomenon, where, as Georg Hegel says, the phenomenon can find the answer in itself. At the same time, it should be understood that such a movement can be different in content and have different semantic content.

Let's look at the treatise of Jose Ortega y Gasset "The Dehumanization of the art" ("La deshumanización del arte", 1925). The treatise was inspired by the presented artistic works, which showed the power of their abilities to create a real image of the world in the art of $19^{\text {th }}$ century and new art, the content of which determines (conditionally) the destruction of this reality.

In the second chapter, "Artistic art", Jose Ortega y Gasset notes: "During the nineteenth century, artists stayed too far from artistic clarity, reducing to the minimum strictly aesthetic elements and making their works consist almost entirely of this fictionalized version of human reality. In this sense it is therefore accurate to say that the art of the past century has been realistic" (Ortega y Gasset, 1991, 225). What in the fifth chapter, "The Call to Understand", is supplemented by the following description: "Works of art preferred in the nineteenth century always contain the nucleus of 'living' reality, which ultimately forms the substance of the aesthetic body. It is this reality that art is occupied with" (Ibid, 236).

Instead, Jose Ortega y Gasset defines the new art of the $20^{\text {th }}$ century in the context of the principle of dehumanization what can be correlated with art, which, according to Georg Hegel, after the realization of its attributes turns against its previous development.

At the end of the second chapter, "Artistic art", Spanish philosopher sets out 7 characteristics of new art. It tends to: (1) "dehumanize art"; (2) "avoid living forms"; (4) "consider art as play and nothing else"; (7) "regard art as a thing of no transcending consequence" (Ortega y Gasset, 1991, 228). And the beginning of such stylistic changes in music is correlated with the works of Claude Debussy: “...This was the accomplishment of Debussy. Only after that it became possible to listen to music calmly, without rapture and without crying... Debussy dehumanized music, so it marks a new era in the art of music" (Ibid, 240-241).

It is now possible to answer the second and third questions defined above and to state the following. In the context of the artistic development of European culture, Impressionism changes the vector of observation and expression of images of the world from intense-dynamic to extensive-contemplative. The perspective of the object characteristic of a work of art also changes. In particular, in music it is not the dramatic principle of unfolding of an artistic image, not logic of formation of structural and expressive elements of a work of art that comes to the fore. These were the features of romantic art. But we see the colourfulness, sophistication of harmonies; focus on the semantic parameters of the image, idea. We can talk about intentional-phenomenological concentration and the phenomenological principle of artistic reflection in music.

A striking example of this is the music of Claude Debussy, which is characterized by: sophistication, uncertainty of the melodic pattern; leading role of theme-impulses, themesymbols; absence of developed, song melodies; weakening attention to thematic development; lack of support for the squareness of structural constructions, broad rhythmic generalizations; denial of the traditional system of harmonies, weakening of functional connections; colourfulness of harmonies; attention to long sounds.

Analysing the work of Claude Monet, Lionello Venturi recalls the words of the friend and biographer Auguste Renoir Georges Riviere at the 1877 exhibition: "Interpretation of the plot for its tone, not for the plot itself - this is what distinguishes the Impressionists from other artists" (Venturi, 2007, 93). 


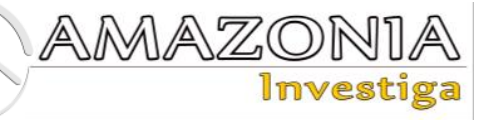

It is obvious from this that the plot and plot drama, which contribute to the formation of a real object role of works of art, are not decisive for the impressionists. Moreover, they are often ignored, while the emphasis is on the intentional focus on the meanings of the completed art.

The following discourse of the article is aimed at determining the deep meaning of Impressionism. At the same time, we will keep in mind the macro-historical analysis and the final intentional period of its formation (the end of the $19^{\text {th }}-21^{\text {st }}$ centuries), in the space of which impressionism arises and develops. The example below shows how, due to the actualization of the factor of procedural nature of the culture and its interpretation as a living social organism, a new perspective opens up in the ontology of cultural and artistic phenomena.

In 1918, Oswald Spengler published the first part of the treatise "The Decline of the West" ("Der Untergang des Abendlandes") in which he noted that at the turn of the nineteenth and twentieth centuries European culture as a living social organism ("Cultures are organisms... History of culture is the progressive realization of its capabilities") passes to the phase of senescence (Spengler, 1993, 262), which accordingly affects the cultural and artistic phenomena of this period. The following definition of impressionism is indicative:

"...They talk about impressionism, not understanding the volume and deeper adequate sense of this concept. It is taken out of the last autumn bloom of art ... What happened? Doesn't this change (emergence in the space of European culture of the phenomenon of impressionism. $O$. O.) indicate that the soul (of culture. $-O$. O.) has imperceptibly disappeared ... a bitter admission that Western art has come to an immutable end..." (Ibid, 464, 467, 473).

Thus, Impressionism is defined not in the context of a critical reaction to Romanticism, which is typical of traditional discourse and to some extent not denied, but on the basis of actualization of procedural and structural existence of culture, the phase of senescence it explains the Impressionism essence.

The reversal of culture and art against its previous development (Hegel), the phase of culture senescence (Spengler), the principle of dehumanization of art (Ortega y Gasset), the intentional / final period of culture and art (Opanasiuk) clearly indicate the characteristics of such development of culture and art. And the peculiarity of this development is the analysis and the result of the completed formation.

If we summarize what has been said and once again actualize the principle of objectivity - the movement to a specific object, which determined the artistic development of European culture during the first two, largely the third periods $\left(5^{\text {th }}\right.$ $-16^{\text {th }}$ centuries; $17^{\text {th }}-18^{\text {th }}$ centuries; $19^{\text {th }}$ centuries) as well as the movement from a specific object, which determines the content of the artistic formation of the late $19^{\text {th }}-21^{\text {st }}$ centuries, - then we can state the following.

First. Cultural and artistic phenomena of the final period of formation of European culture are determined by the intentional reflection of culture, which it forms in this period. Intentional reflection involves "figurative and semantic focus (of culture) on the cultural and artistic attributes and meanings formed in previous periods, the purpose of which is the analysis of the accomplished... Formation and projection of possible new development (of culture)" (Opanasiuk, 2020, 224).

Second. One way or another, the artistic and stylistic phenomena of the final period are caused by the movement from a (specific) object towards its periphery or deep sphere. According to the content and principle of artistic expression, such a movement can be different and have different semantic content. If we take into account that after the implementation of its program, art turns against the previous development, resorts to irony (about what has been done), and also seeks answers to various questions in itself (Hegel, 2007, 611, 613), then it is easy to understand the directions of such movement.

These can be different repetitions of previous artistic and stylistic phenomena (neo-style, poststyle, polystylistics), focusing on their semantic nature (impressionism, symbolism, sonorism), moving towards the periphery of the semantic sphere of phenomena (minimalism, constructivism, structuralism), strengthening and exacerbation of semantic moments of phenomena (expressionism - sharpened reflection of romanticism), etc.

Third. Obviously, Impressionism belongs to a larger phenomenon - to the intentionalism of culture, the period when culture realizes its attributes, focuses on past development, forms intentional reflection and intentional style. In the context of stylistic characteristics, it can be stated that Impressionism is a component of intentional 
style - an expression of completed cultural and artistic existence (Opanasiuk, 2014). At the same time, Impressionism expresses only one aspect of movement from a (specific) object and is directed to its (object) deep sphere. The originality of the impressionist style is due to the phenomenological principle of artistic reflection. In this case, Impressionism has much in common with symbolism. The difference between them is that symbolism seeks to express the very phenomenological meaning of the symbol, while Impressionism, so to speak, scans the figurative meanings of phenomena and focuses on the modelled artistic image.

Let's explain this with examples. In "Afternoon of a Faun" ("L'Après-midi d'un faune", 1894) by Claude Debussy the stylistic basis of Impressionism is obvious, but its content determines the intentional-phenomenological focus on the artistic and expressive meanings of Romanticism. Obviously, this cannot be unambiguously interpreted as a denial of the latter. In the final period of cultural development, romanticism already belongs to the past and loses its relevance, while the analysis of the completed cultural and artistic formation becomes important. Such relations of impressionism and romanticism in this work are pointed out by David Cod: "The faun, the poem's main "character", comes to symbolize the reader's divided experience of a text composed on the cusp of a loss of Romantic lyricism to modernist impersonality... A division between hearing and analytical reading is created... the Romantic orchestral poetics exemplified... is losing its immediacy, and the Romantic harmony that attained an expressive limit in Wagner's music dramas is being broken up by systematic analysis" (Code, 2001).

The same can be said of the piano piece "The joyful island" ("L'Isle joyeuse”, 1903-1904), and many Preludes for piano (1910-1913). Therefore, we can say that in the works of the late nineteenth - early twentieth century Debussy expressed the urgent request of culture at the level of phenomenological comprehension of its accomplished existence

We find something else in the works of Maurice Ravel ("Reflection" / "Miroirs", 1905; "Night Gaspar" / "Gaspard de la nuit", 1908; "Noble and sentimental waltzes" / "Valses nobles et sentimentales", 1911): Impressionist reflection is preserved (intentional-phenomenological focus on the artistic and expressive meanings of romanticism is relevant), but it is complemented by stylistic and figurative intentions of neoclassicism, which gives reason to position Ravel's musical poetics in these works in the context of principles of intro-retro-speculation and compilation and phenomenology.

\section{Conclusions}

Any artistic and stylistic phenomena belong to a certain period of formation of culture, the content of which they express. At the same time, each epoch inheres to the space of culture, the formation content of which it determines. At the macro-historical level, this means that cultural and artistic phenomena are due to the procedural and structural existence of culture.

During three periods $\left(5^{\text {th }}-16^{\text {th }}\right.$ centuries; $17^{\text {th }}-$ $18^{\text {th }}$ centuries; $19^{\text {th }}$ centuries) the artistic development of European culture was determined by the desire to express the reality of images of the world in their object perspective. After the achievements in the late nineteenth (beginning of the final intentional period) the vector of observation and expression of images of the world changes. The object perspective loses its relevance, but the movement from the (specific) object towards the periphery and to the deep dimension of phenomena becomes decisive for art. According to the content and principle of artistic expression, such a movement can be different and have different semantic content.

As a style, Impressionism belongs to a larger phenomenon - to the intentionalism of culture, a period when culture realizes its attributes and focuses on accomplished development. Impressionism expresses only one aspect of movement from a (specific) object and is directed to its (object) deep sphere. The originality of the impressionist style is due to the phenomenological principle of artistic reflection. Impressionism has much in common with symbolism. The difference between them is that symbolism expresses the very phenomenological meaning of the symbol, while Impressionism scans the figurative meanings of phenomena and focuses on the modelled artistic image.

\section{Bibliographic references}

Balmer, Y., Lacôt, T., \& Murray, C.B. (2016). Messiaen the Borrower: Recomposing Debussy through the Deforming Prism. Journal of the American Musicological Society, 69 (3), pp. 699-791.

Bomford, D. (1991). Impressionism: Art in the Making / by David Bomford, John Leighton, Jo Kirby, Ashok Roy. London: National Gallery. 


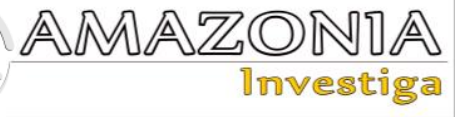

Code, D.J. (2001) Hearing Debussy reading Mallarmé: Music after Wagner in the Prelude to the Afternoon of a Faun. Journal of the American Musicological Society, 54(3), pp. 493-554.

Eisenman, S.F. (2011). From Corot to Monet: The Ecology of Impressionism. Milan: Skira.

Elferen, I. (2017). Drastic Allure: Timbre Between the Sublime and the Grain. Contemporary music review, Vol. 36, Part 6, pp. 614-632.

Gumilev, L. (2005). Ethnogenesis and biosphere of the Earth. Moscow: AST. (In Russian)

Hegel, G. W. F. (2007). Lectures on Aesthetics. In Two Volumes. 2nd stereotype edition. Saint Petersburg: Nauka. Vol. I.

Kennedy, M. (2006). Impressionism, in Music. The Columbia Encyclopedia, sixth edition. New York: Columbia University Press.

Kushniruk, O. (2008). Impressionism. Ukrainian Music Encyclopedia. Head. ed. Skripnik G., deputy heads. ed. Kalenichenko A, Sikorska I. Kyiv: IMFE. vol. 2, pp. 203-205.

Malherbe, C. (2000). Seeing Light as Color; Hearing Sound as Timbre. Contemporary music review, Vol. 19, Part 3, pp. 15-27.

Mawer, D. (2000). The Cambridge Companion to Ravel. Edited by Deborah Mawer. Cambridge University Press.

Nichols, R. (2011). Ravel. New Haven; London: Yale University Press.

Opanasiuk, O. (2020). Intentionality in the Realm of Culture: Art Critical, Culturological, and Philosophical Aspects:
A Monograph, 3rd revised and augmented edition. Kyiv: Osvita Ukrainian.

Opanasiuk, A. (2014). On the definition of intentional style of art. Observatory of Culture. Moscow: FBGU, Russian State Library, pp. 4-10.

Ortega J. y Gasset, H. (1991). The Dehumanization of art. Aesthetics. Philosophy of Culture. Introductory article by Friedlander G; Compiled by Bagno V. Moscow: Isskustvo, pp. 218-260.

Palmer, C. (1973). Impressionism in Music. London: Hutchinson.

Rewald, J. (1973). The History of Impressionism (4th, Revised Ed.). New York: The Museum of Modern Art.

Spengler, O. (1993). The Decline of the West: Outlines of a Morphology of World History. Vol. 1. Form and Actuality. Translated from the German, prefaced and annotated by Karen Swassjan. Moscow: Mysl'.

Toynbee, A. (1995). The study of history. Volume 1 / [trans. from English V. Shovkun]. Kyiv: Osnovy.

Trezise, S. (2003). The Cambridge Companion to Debussy. Edited by Simon Trezise. Cambridge University Press.

Venturi, L. (2007). From Manet to Lautrec. St. Petersburg: Azbuka-classica, pp. 330-331.

Vuillermoz, E. (1957). Claude Debussy. Paris: Flammarion.

World art. (2008) (Illustrated encyclopedia: Directions and currents from impressionism to the present day) / Compiler Mosin I. St. Petersburg: Szkeo, pp. 52-57. 